\section{Employment in a rainforest}

SIR - Are any readers interested in working in a tropical rainforest?

I recently paid a visit on behalf of the Royal Society to the Danum Valley Field Centre in the state of Sabah, East Malaysia (formerly British North Borneo). Nearly one million hectares of rainforest in Sabah (about 15 per cent of the total land mass) have been allocated to the Sabah Foundation, a non-profit-making trust set up by the local people to support a programme of education, welfare and health. Two large areas remain untouched and committed as conservation areas; most of the rest is used for 'sustainable forestry'. Initially, in 1966, this involved logging followed by regeneration so that the productive timber resources were maintained in perpetuity. More recently the foundation has come to realize that future generations in Sabah and elsewhere require 'sustainability' not just of the timber resources but of the entire ecosystem. They are now seeking to adopt forestry practices that protect the environment and do minimal damage to the tremendous diversity of plant and animal life that characterizes tropical rainforests.

The field centre sits at the boundary between untouched primary forest in the $438-\mathrm{km}^{2}$ Danum Valley Conservation Area and forest that has been logged at various known times by various specified procedures. It offers unique opportunities to study the natural biodiversity of the forest, how it is disturbed by logging and to what extent it regenerates. Research projects are in progress on rainforest dynamics, soil water and stream hydrology, erosion, rehabilitation by enrichment planting, insect diversity, fish populations, mouse deer radiotracking, orang-utan feeding habits and much more. The Royal Society provides some core support and scientific coordination and the centre is managed by a consortium that includes the Sabah Foundation, the Sabah Forestry Development, the local Ministry of Tourism and Development and the Sabah Campus of the National University of Malaysia.

The research opportunities are unbounded, and the resources of the centre more than adequate for the number of researchers working there. Malaysian scientists involved with the programme are enthusiastic but few in number and inevitably much of their time is taken up by administration and teaching the next generation of science students. British scientists are welcome: either senior scientists for shorter working visits, if possible combined with lecture courses at the university, or postdocs or graduate students working for higher degrees.

For further information, write to either Dr Clive Marsh, Assistant General Mana- ger (Conservation and Environmental Services), Forestry Division, Innoprise Corporation Sdn Bhd, PO Box 11623, 88817 Kota Kinabalu, Sabah, Malaysia, or Dr Stephen Sutton, Royal Society Research Programme Coordinator, Heigh Head, Mewith, Bentham, Lancashire LA2 7AU, UK.

\section{Anne McLaren}

(Foreign Secretary)

Royal Society,

6 Carlton House Terrace,

London SW1Y 5AG, UK

\section{Education in India}

SIR - I should like to suggest some ways of remedying the present parlous state of higher education in India.

In the first place, science and technology should be included with the education portfolio at the centre, as it was when Maulana Azad was Union Education Minister; when Justice M. C. Chagla was made education minister in Nehru's cabinet, science and technology were included in his portfolio.

Second, the universities should be removed from the control of state governments and brought under the direct administrative control of central government, where the University Grants Commission (UGC) can monitor academic growth properly rather than merely distributing funds. This will help to create a national outlook on higher education.

Third, the UGC budget, which has remained constant during the past three years, should be increased in the light of current needs.

Fourth, 10 per cent of the science and technology budget should be earmarked for training in universities and colleges. The present allocation to science of 0.9 per cent of gross national product (GNP) is even less than what was spent in the 1980 s (1.3 per cent). This needs to be raised to a minimum of 8 per cent of GNP.

What has gone wrong with Indian universities? When the British left India in 1947, they left four universities - Allahabad, Bombay, Calcutta and Madras with high standards of scholarship and learning and with full autonomy. When India became independent, universities came under the control of state governments and, in the name of economic control, universities lost their autonomy and petty bureaucrats dictated day-to-day functioning. The downward path was also heralded with the creation of Institutes of Technology (IITs) totally divorced from the academic life of universities. Universities were starved of funds as major resources were diverted to the creation of IITs. With the passage of time, the IITs have become academic ciphers like the universities. There is talk in India of granting national laboratories university status and allowing them to award degrees. This would drive the last nails into the coffin of the already moribund university system.

Finally, India must realize that national laboratories must be made subservient to industrial research needs. National laboratories must help towards industrial development to make India self-sufficient in production and in technical know-how. Basic science and research should, by and large, be left to the universities. Of course, no laboratory can function without some work in basic sciences, but this should be seen as a secondary function of the laboratories, and not their primary function.

John Maddox has rightly said (Nature 366, 627; 1993) that "India is lucky in knowing what it needs". The knowledge of one's needs is not sufficient if one does not have the moral courage and mental calibre to muster means. The demoralized academic community in India needs the means to steer its path through a selfdefeating bureaucratic system coupled with political ignorance of the importance of academic and scientific excellence for attaining social justice.

\section{A. N. Malviya}

5, rue Blaise Pascal,

67084 Strasbourg, France

\section{Jobs for the girls?}

SIR - The discussion of "social science and the new world order" (Nature 366, 403 ; 1993) raises a pertinent question can the example of Kerala, where the birthrate has fallen dramatically, be copied elsewhere? Even other Indian states could not emulate Kerala. There is thus a need to look more critically at this success story.

Even if it is possible to provide the necessary infrastructure for education, there is no guarantee that it would be used, because there has to be a perceived benefit from education that would motivate families to educate their children (especially girls).

Kerala succeeded by providing a perceived link between female literacy and female job opportunities. In Kerala, women make up a much higher proportion of the workforce than elsewhere in India -35 per cent overall, 45 per cent in the private sector. Education without job opportunities will not bring about the classical demographic transition.

\section{Shashi Kant}

Department of Medicine,

L. R. Murmu

Department of Surgery,

All India Institute of Medical Sciences,

New Delhi 110029, India 